АСПЕКТИ ФОРМУВАННЯ КОРПОРАТИВНОЇ КУЛЬТУРИ У БАНКІВСЬКОМУ СЕКТОРІ УКРАЇНИ

\title{
ASPECTS OF FORMATION OF CORPORATE CULTURE IN THE BANKING SECTOR OF UKRAINE
}

\begin{abstract}
у статmі розглянуто засади фрормування корпоративної культури у вітчизняних банківських установах. В аспекті визначення передумов створення ефрективної корпоративної культури банку акцентовано увагу на таких критеріях успішності банківських установ, як стресостійкість, лояльність вкладників та місце в ренкінгу по депозитах фрізичних осіб, що постійно моніторяться міністерством орінансів України. Під час дослідження проблеми акцентовано увагу на основних проблемних моментах слоганів вітчизняних банківських установ, проведено їх порівняльну характеристику з девізами іноземних банків в аспекті доступності, інорормативності та повноти інформації про місію банків. У статmі виокремлено основні постулати корпоративної культури. Зазначено, що корпоративна культура є складовою частиною корпоративного управління банком, що визначається основним стейкхолдером, а саме державою в особі Міністерства фрінансів, та клієнтами (споживачами банківських продуктів). Зосереджено увагу та твердженні, що ідеальне значення корпоративної культури лежить в основі квадрату видів організаційної культури, векторами якого є співпраця, створення, контроль, конкурениія. Розмір кожного вектору для кожного окремо взятого банку є різним і визначається вибраною стратегією розвитку, а саме орієнтирами, місією, цілями, планами.

Ключові слова: банківські установи, корпоративна культура, організаційна культура, корпоративне управління, рейтингування банків, ризик втрати репутації.
\end{abstract}

В статье рассмотрены основы фороми рования корпоративной культуры в оте- чественных банковских учреждениях. В аспекте определения предпосылок создания эффрективной корпоративной культуры банка акцентировано внимание на таких критериях успешности банковских учреждений, как стрессоустойчивость, лояльность вкладчиков и место в ренкинге по депози там фризических лиц, которые постоянно мониторятся Министерством финансов Украины. При исследовании проблемы акцентировано внимание на основных проблемных моментах слоганов отечественных банковских учреждений, проведена их сравнительная характеристика с девизами иностранных банков в аспекте доступности, информативности и полноты информации о миссии банков. В статье выделены основные постулаты корпоративной культуры. Указано, что корпоративная культура является составной частью корпоративного управления банком, которое определяется основным стейкхолдером, а именно государством в лице Министерства фринансов, и клиентами (потребителями банковских продуктов). Сосредоточено внимание на утверждении, что идеальное значение корпоративной культуры лежит в основе квадрата видов организационной культуры, векторами которого являются сотрудничество, создание, контроль, конкуренция. Размер каждого вектора для каждого отдельно взятого банка является различным и определяется выбранной стратегией развития, а именно ориентирами, миссией, целями, планами.

Ключевые слова: банковские учреждения, корпоративная культура организационная культура корпоративное управление, рейтингование банков, риск потери репутации.

State University of Banking
Stand

The article considers the principles of formation of corporate culture in the domestic banking institutions. Topicality of the research is due to permanent and neutrino attention of the theory and practice of management to the personnel management system, creation of favorable psychological climate in the organization and ensures effective corporate culture. In the aspect of determining the prerequisites for the establishment of good corporate culture the Bank has focused on such criteria for the success of banking institutions as stress, the loyalty of investors and a place in the ranking for retail deposits, which is constantly monitored by the Ministry of Finance of Ukraine. We have studied the ranking of banks according to national rating, according to which the first position is the Internet bank "Monobank", which offers the convenience and speed of service and a large percentage of cash back on many types of transactions. The study problem focused on the main problematic moments of the slogans of domestic banking institutions, their comparative characteristics with the motto of foreign banks in the aspect of accessibility, informativeness and completeness of the information about the mission of the banks. Judging from the diversity of the mottos of the Ukrainian banks, we can infer the existence of two types - the General slogan that is part of the brand, and a slogan developed for a specific advertising campaign or product. The situation with regard to the first case is quite problematic, as common phrases may not carry to the consumer any information about the Bank or about his product. The main principles of corporate culture are highlighted in the article. It is stated that corporate culture is a component of corporate governance of the bank, which is determined by the main stakeholder - the state represented by the Ministry of Finance and clients (consumers of banking products). The focus and the statement that the ideal value of corporate culture is at the heart of the square of types of organizational culture, the vectors of which are: cooperation, creation, control, competition. The size of each vector for each individual bank is different and is determined by the chosen development strategy - benchmarks, mission, goals, and plans.

Key words: banking institutions, corporate culture organizational culture corporate governance, bank rating, reputation risk.

Постановка проблеми. Умови сьогодення не лише визначають споживача та виробника, але й ідентифрікують потреби й шляхи їх задоволення. Підприємство як суб'єкт господарювання повинне мати ознаки, що не лише відрізняють його від інших гравців на ринку, але й формують його індивідуальність, можливість диференціації на вибраному сегменті ринку. Ознаками дисеренціації, окрім завжди згадуваних ознак якості, стимулювання збуту, реклами, та післяпродажного обслуговування, є організаційна (корпоративна) культура. Такий засіб диференціації, як корпоративна культура, потребує додаткового дослідження та актуалізації. 
Аналіз останніх досліджень і публікацій. Корпоративну культуру як поняття та інструмент есрективного менеджменту підприємства у своїх наукових працях розглядали такі вітчизняні й зарубіжні науковці, як Т. Алексєєв, В. Гаєвський, Ю. Давидов, Г. Дмитренко, В. Кравченко, М. Коул, Т. Кицак, А. Маслов, Б. Мільнер, В. Никісоренко, М. Портер, Т. Пітерс, Г. Хаєт, С. Хенді, Г. Чайка, М. Чеплюк.

Постановка завдання. Метою статті $€$ виявлення особливостей та проблемних моментів у формуванні корпоративної культури у вітчизняних банківських установах. Актуальність статті визначається дослідженням пріоритетних для формування есрективної системи менеджменту у банківських установах напрямів командоутворення.

Виклад основного матеріалу дослідження. Сьогодні в аспекті численних досліджень та трактувань понять «корпоративна культура» та «корпоративна етика» недостатньо обґрунтованими $€$ можливі тенденції зміни засад кодексів корпоративної етики вітчизняних підприємств за умови євроінтеграції України та глобалізації світових ринків капіталу.

Для окреслення загальних тенденцій на ринку банківських послуг та імплементації досвіду фоормування засад корпоративної культури варто звернутись до рейтингів банківських установ.
Міністерство фрінансів складає рейтинг банків України за кількома основними показниками, такими як стресостійкість, лояльність вкладників, оцінювання аналітиків та місце в ренкінгу по депозитах фрізичних осіб. В аспекті досліджуваної проблеми, а саме взаємозв'язку корпоративної культури та стратегії підприємства (банку), доцільно зазначити, що висвітлені показники в рейтингу Міністерства фрінансів мають у своєму складі частку вагомості впливу організаційної культури як невід'ємної частини внутрішньогопотенціалу банку.

Окрім рейтингу банків за вищезазначеними критеріями, Міністерство фрінансів надає перелік огляду відгуків про банк, його продукти та персонал. Такі огляди допомагають клієнту вибрати банк для власного обслуговування за певними критеріями. Варто зауважити, що найбільше відгуків на діяльність $€$ у «Приватбанку», напевно, тому, що він займає найвищу позицію в рейтингу за ознаками «Залежність від вкладів фрізичних осіб» та «Частка банку на ринку роздрібних депозитів», а це означає, що він обслуговує найбільше за всі наведені установи фрізичних осіб. Визначальним в аспекті вивчення категорії корпоративної культури банку $є$ те, що на всі відгуки, а вони можуть мати негативний та проблемний характер, банк дає відповідь і зобов'язується допомогти у вирішенні проблемної ситуації [1].

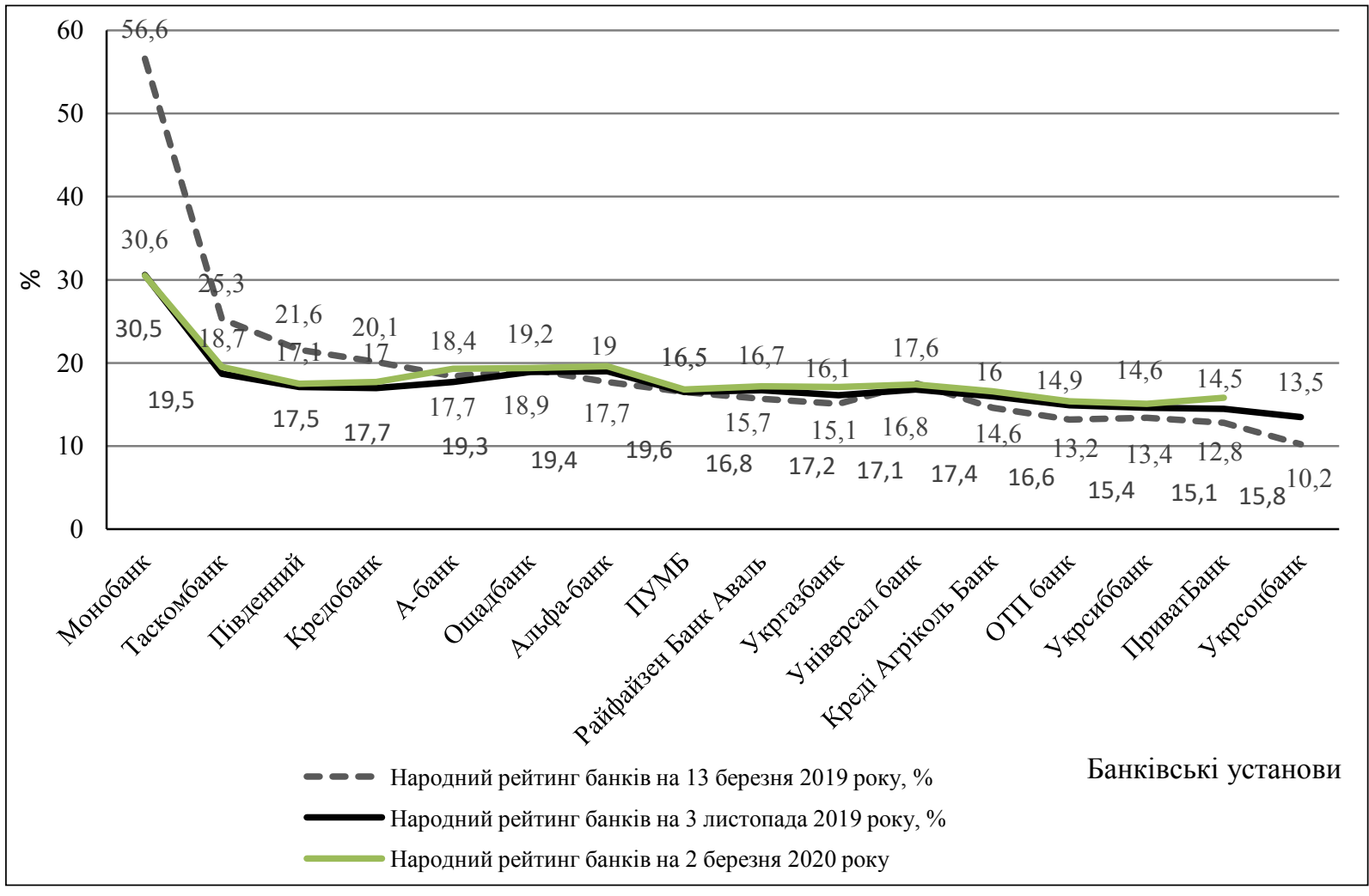

Рис. 1. Місце деяких вітчизняних банків у народному рейтингу на 13 березня та 3 листопада 2019 року, на 2 березня 2020 року

Джерело: складено автором на основі [1] 
За народним рейтингом ситуація може бути дещо іншою, адже на ринку банківських послуг з'явився новий гравець, а саме інтернет-банк "Monobank", що пропонує зручність та швидкість обслуговування та великий відсоток "cash back" за багатьма видами операцій. Популярність цього банку становить 56,56\%. Потужним конкурентом для нього за зазначеним рейтингом $€$ «Таскомбанк» (складова частина Групи «ТАС»), що завоював популярність у населення (23,5\%) завдяки тому, що за підсумками I кварталу 2018 року став лідером темпів приросту депозитів приватних клієнтів (рис. 1) [2].

Народний рейтинг будується на підставі відгуків відвідувачів сайту Мінсріну про якість обслуговування в банках. На позицію банку впливають лише відгуки, перевірені модераторами Міністерства фрінансів України. Як видно з динаміки зазначеного показника, місце деяких банків у народному рейтингу похитнулося, що зумовлене, швидше за все, зростанням популярності інших банків та частково задоволеним попитом у «нових банківських інноваціях» 3 боку «Монобанку». Приплив банківського іноземного капіталу в Україну зумовив проникнення західного стиля менеджменту в систему управління вітчизняними банками. Пропонуючи своїм клієнтам широкий та різноманітний спектр все нових та нових продуктів, банки все частіше заявляють про себе як про соціально відповідальні компанії, фрормують власну корпоративну культуру.

Дослідники поняття всі засоби корпоративної культури поділяють на видимі (відчутні) та невідчутні. Видимі засоби є відчутними як для працівників компаній, так і для клієнтів та іншого зовнішнього оточення (фрірмовий одяг, емблема, дизайн тощо). Деякі елементи корпоративної культури надзвичайно важко описати, адже вони $є$ неосяжними для оточуючих і лише команда банку добре знайома з цими елементами.

Основою корпоративної культури, що допомагає як співробітникам, так і клієнтам, контрагентам оцінити соціальну роль організації кожної банківської установи, $є$ місія банку. Вона визначає основні орієнтири діяльності і $є$ відомою для всіх стейкхолдерів (табл. 1) [3].

Судячи $з$ усієї розмаїтості девізів українських банків, можемо зробити висновок про існування двох їх типів, таких як загальний слоган, що $€$ частиною бренду банку, й слоган, розроблений для конкретної рекламної кампанії або продукту. Ситуація, що стосується першого випадку, досить проблемна, оскільки загальні фррази можуть не нести для споживача жодної інфооммації ні про банк, ні про його продукт. Слогани можуть нести

Місії окремих банківських установ в Україні

Таблиця 1

\begin{tabular}{|c|c|c|}
\hline Банк & Слоган & Місія \\
\hline ПАТ «ПриватБанк» [4] & $\begin{array}{c}\text { Банк для тих, хто } \\
\text { йде вперед. }\end{array}$ & $\begin{array}{c}\text { Допомагати економіці розвиватися, бізнесу - зростати, а приватним } \\
\text { клієнтам - здійснювати мрії шляхом надання фінансових послуг } \\
\text { найвищої якості. }\end{array}$ \\
\hline ПАТ «ПУМБ» [5] & $\begin{array}{c}\text { Працюємо для } \\
\text { Вас. }\end{array}$ & 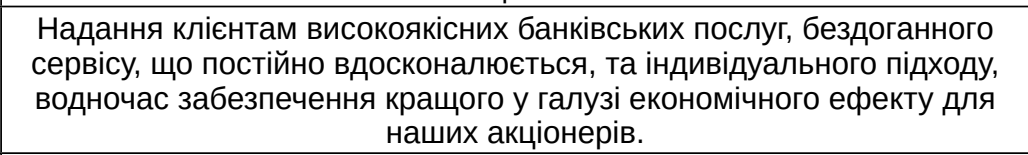 \\
\hline ПАТ «Кредобанк» [6] & Час жити краще! & $\begin{array}{c}\text { Ми є надійним фрінансовим партнером для наших клієнтів і } \\
\text { привабливим роботодавцем для наших працівників. Завдяки } \\
\text { спеціалізації та концентрації ресурсів хочемо досягти довгострокової } \\
\text { стабільності нашого бізнесу й підтримувати її, забезпечуючи } \\
\text { рентабельність інвестицій наших акціонерів. }\end{array}$ \\
\hline АБ «Укргазбанк» [7] & $\begin{array}{l}\text { Консерватизм } \\
\text { у традиціях } \\
\text { - інновації в } \\
\text { технологіях. }\end{array}$ & $\begin{array}{c}\text { Полягає в кредитуванні вітчизняних підприємств та населення, } \\
\text { наданні їм повного спектру високоякісних банківських послуг для } \\
\text { забезпечення відновлення економіки України, стабільного зростання } \\
\text { валового внутрішнього продукту. }\end{array}$ \\
\hline АБ «Південний» [8] & $\begin{array}{l}\text { Ми проєктуємо } \\
\text { Ваш успіх. }\end{array}$ & $\begin{array}{c}\text { Ми прагнемо використовувати весь потенціал банку, стабільно } \\
\text { працюючи й залучаючи нових клієнтів в будь-який час, особливо в } \\
\text { період вимушеного фрінансового затишшя. }\end{array}$ \\
\hline $\begin{array}{c}\text { ПАТ «Райсрфрайзен } \\
\text { Банк Аваль» [9] }\end{array}$ & $\begin{array}{l}\text { Разом змінимо } \\
\text { країну. } \\
\text { Європейський } \\
\text { банк поруч. } \\
\end{array}$ & $\begin{array}{c}\text { Ми - надійний та відповідальний банк, що наполегливо та } \\
\text { профресійно працює задля зростання добробуту наших клієнтів, } \\
\text { співробітників та суспільства. }\end{array}$ \\
\hline ДБ «Ощадбанк» [10] & $\begin{array}{l}\text { Мій банк. Моя } \\
\text { країна. }\end{array}$ & $\begin{array}{c}\text { Забезпечення населення надійним фінансовим інструментом } \\
\text { тривалого та гарантованого заощадження, а також підтримка } \\
\text { економічного розвитку держави шляхом надання сучасних } \\
\text { банківських послуг. } \\
\end{array}$ \\
\hline $\begin{array}{c}\text { ПАТ «Універсал Банк» } \\
\text { [11] }\end{array}$ & $\begin{array}{l}\text { Ми віримо в } \\
\text { Україну! Будуймо } \\
\text { майбутнє разом! }\end{array}$ & $\begin{array}{c}\text { Зміцнення віри українців в майбутнє країни й підвищення довіри } \\
\text { до банківської системи, надання людям упевненості в ї банку, } \\
\text { відображення того, що “Universal Вапк” в Україні розвивається } \\
\text { серйозно й надовго. }\end{array}$ \\
\hline
\end{tabular}


інформацію, зорієнтовану на споживача та його потреби («Ми проєктуємо Ваш успіх!»), а можуть мати з огляду на політичну ситуацію, що склалась, патріотичне забарвлення («Ми віримо в Україну! Будуймо майбутнє разом!»).

На жаль, менеджмент вітчизняної банківської системи, розробляючи свій бренд, не завжди користується прямою доцільністю діяльності банку, тому слогани українських банків не можна порівняти з девізами західних колег, зокрема:

- загальновизнана довершеність: "Citi group Your city never sleeps” («Твоє місто (сіті) ніколи не спить»);

- "US Bank - Other banks promise great service, U.S.Bank guarantees it" («lнші банки обіцяють гарний сервіс, U.S.Bank гарантує його»);

- "Deutsche Bank - A passion to perform" («Пристрасть до втілення»);

- "HSBC Holdings - The world's local bank" («Всесвітній місцевий банк») [12].

Основні категорії, що описані в місії банку, знаходять своє відображення у його стратегії та корпоративній культурі. Варто зауважити, що здебільшого комерційні банки є складовими певних інтегрованих корпоративних структур, отже, в місії банку закладено основу діяльності певної Структури чи Групи.

Отже, підсумовуючи аналіз засад корпоративної культури вітчизняних банківських установ, зауважуємо, що корпоративна культура є інтегрованим поняттям, що має місце у фрормуванні місії банку, організації його діяльності та впливає на основні показники його діяльності.

Проте не лише зарубіжні компанії мають позитивний досвід в організації своєї особливої культури. Варто згадати «ПриватБанк», який у сучасній українській банківській системі є зразком того, як потрібно організувати маркетингову роботу, що стала вирішальною в успіху компанії. Також вплинула на успіх компанії особлива корпоративна культура. Своїх працівників вони виховують у дусі постійної прихильності до банку, націленої на інновації діяльності, регулярного досягнення ефективності у своїй роботі. Загалом корпоративну культуру можна звести до кількох постулатів, таких як:

- поведінка згідно з нормами етикету;

- виваженість та ефрективність у прийнятті рішень;

- клієнт завжди правий, і навіть коли він не правий, він правий;

Постійна робота з персоналом, якісна маркетингова політика та стабільна корпоративна культура дають змогу «ПриватБанку» ефективно та якісно обслуговувати своїх клієнтів. Окремі негативні випадки в окремих відділеннях ми не враховуємо [13].

Корпоративна культура $€$ складовою частиною корпоративного управління банком, що визначається основним стейкхолдером, а саме державою в особі Міністерства орінансів, та клієнтами (споживачами банківських продуктів).

Структура корпоративного управління банком включає певний перелік регулюючих та контролюючих органів.

Корпоративне управління визначає розподіл повноважень та обов'язків, на підставі яких правління та вище керівництво банку веде діяльність та справи банку, включаючи те, як вони:

- визначають стратегію та цілі банку;

- відбирають персонал та здійснюють нагляд за ним;

- керують банківською діяльністю на щоденній основі;

- захищають інтереси вкладників, виконують зобов'язання зацікавлених сторін та беруть до уваги інтереси інших визнаних зацікавлених сторін;

- узгоджують корпоративну культуру, корпоративну діяльність та поведінку з очікуванням того, що банк буде вести свою діяльність у безпечний та надійний спосіб, добросовісно та відповідно до чинних законів та нормативно-правових актів, а також запроваджувати функції контролю [14].

Держава реалізує свої права власника «ПриватБанку», а органи управління Банком діють відповідно до найкращих світових практик корпоративного управління, зокрема Принципів організації економічного розвитку та співробітництва щодо корпоративного управління для підприємств 3 державною часткою (OECD Guidelines on Corporate Governance of State-Owned Enterprises), Принципів корпоративного управління для банків Базельського комітету з банківського нагляду (Corporate governance principles for banks by Basel Committee on Banking Supervision), Рекомендацій Європейської банківської організації щодо внутрішнього управління (Guidelines on Internal Governance by European Banking Authority), що застосовуються в обсязі, що не суперечить імперативним нормам чинного законодавства України [4].

Принципи, що містяться в документі Організації економічного розвитку та співробітництва щодо корпоративного управління для підприємств 3 державною часткою (OECD), базуються на досвіді країн-членів, які вдавалися до таких спроб у національному масштабі, а також на результатах роботи, що раніше проводилась ОЕСР.

Вагомий внесок у розроблення Принципів також зробили країни, що не є членами ОЕСР, а також Світовий Банк, Міжнародний валютний фронд, ділові кола, інвестори, просрспілки та інші зацікавлені сторони (табл. 3).

Рекомендації Базельського комітету взяті 3 принципів корпоративного управління, опублікованих Організацією економічного співробітництва і розвитку (OECD). Широко й давно затверджені принципи OECD мають на меті допомогу 
урядам у їхніх діях щодо оцінювання та покращення принципів корпоративного управління, надання рекомендацій учасникам та регуляторам фрінансових ринків [14].

Підвищена увага до ризику та супровідні принципи управління включають визначення обов'язків різних сторін організації щодо подолання ризиків та управління ними. Часто вони називаються трьома лініями захисту, кожна 3 яких відіграє важливу роль. Напрям бізнесу - це перша лінія захисту, що має «право власності» на ризик, через яке він підтверджує ризик, на який наражається під час ведення діяльності, та управляє ним. Підрозділ управління ризиками відповідає за подальше виявлення, вимірювання, моніторинг та звітність щодо ризику на рівні підприємства в рамках другої лінії захисту незалежно від першої лінії захисту. Підрозділ контролю за дотриманням норм ("compliance") також вважається частиною другої лінії захисту. Підрозділ внутрішнього аудиту відповідає за третю лінію захисту, проводячи аудиторські перевірки на основі оцінювання ризиків та загальні аудиторські перевірки й аналіз, щоби запевнити правління в тому, що загальні принципи управління, включаючи принципи управління ризиками, є ефективними, а політика та процедури запроваджені й послідовно виконуються.

Очікується, щосередобов'язківчленівправління та вищого керівництва буде визначення ризику поведінки на основі середовища бізнесу банку.

Випадки неналежної поведінки були визначені як такі, що походять від:

- неправильного продажу фінансових продуктів роздрібним та бізнес-клієнтам;

- порушення національних та міжнародних правил (податкових норм, норм протидії відмиванню коштів, норм протидії фрінансуванню тероризму, економічних санкцій тощо);

- маніпуляцій на фрінансових ринках, наприклад маніпуляцій ставками Libor та обмінними курсами.

Правління має визначити «атмосореру нагорі» та здійснювати нагляд за роллю керівництва у збереженні надійної корпоративної культури та культури ризику. Керівництво має створити письмовий кодекс етики або кодекс поведінки. Обидва кодекси мають на меті просування культури чесності та підзвітності задля захисту інтересів клієнтів та акціонерів.

Отже, корпоративна культура українських банків - це відносно нове й недостатньо досліджене явище, яке останнім часом привертає дедалі більшу увагу дослідників у галузі управління.

Створення сучасної інтегрованої системи управління персоналом нині вважається однією з основних умов реалізації стратегії банківської установи. Практичний досвід засвідчує, що підвищенню мотиваційного потенціалу корпоративної культури управління сприяє її соціальна відповідальність, а також акцентування уваги на якості трудового життя організації. Це дає змогу корпоративній культурі працювати на створення конкурентоспроможного іміджу організації, залучати потенційних клієнтів і висококваліфріковані кадри, бути мотиваційним механізмом для всіх співробітників і, як наслідок, подолати свою амбівалентність, конфрлікт корпоративних і суспільних цінностей. На досягнення цих цілей повинен бути спрямований управлінський аспект корпоративної культури.

Ідеальне значення корпоративної культури лежить в основі квадрату видів організаційної культури, векторами якого є:

- співпраця;

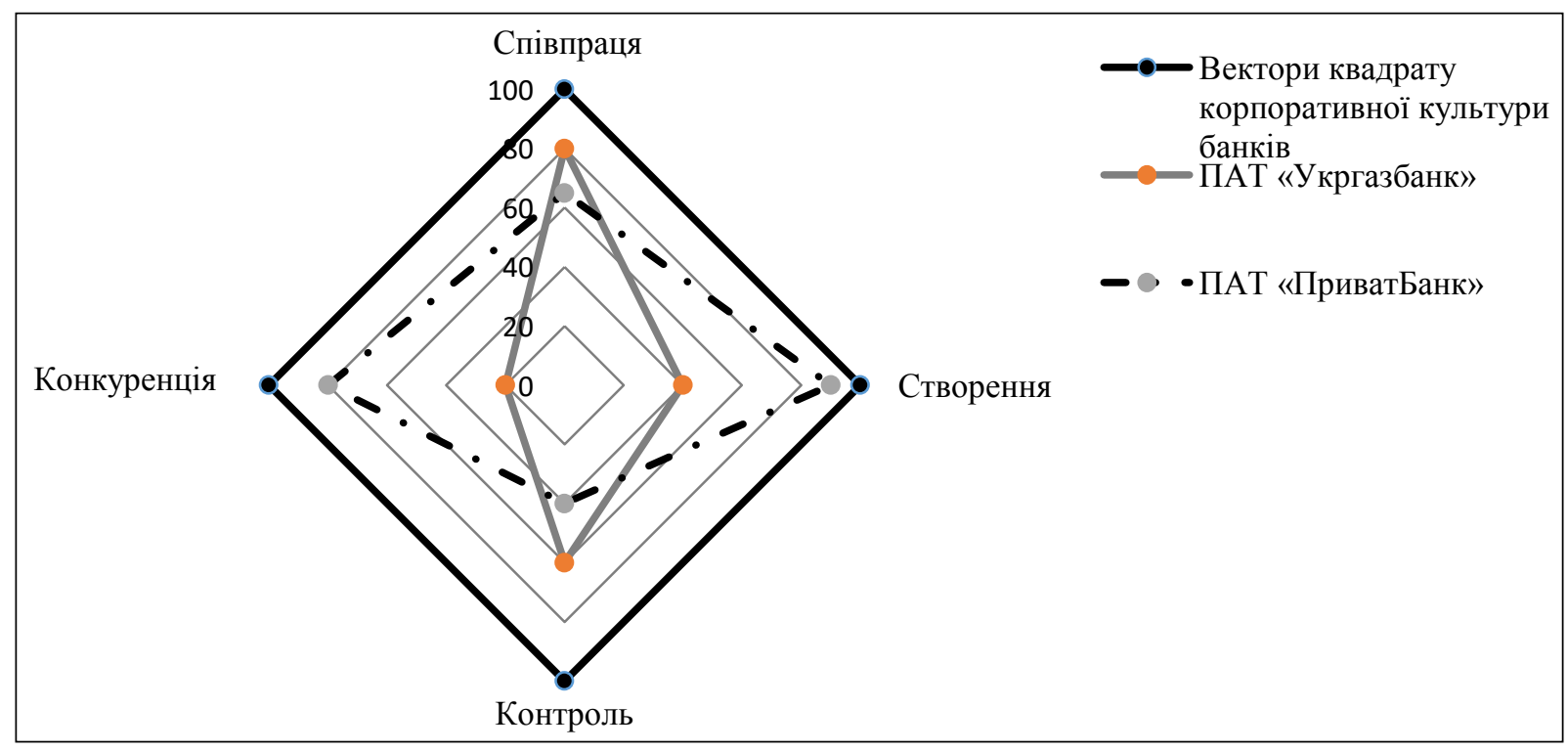

Рис. 2. Квадрат векторів організаційної культури 
- створення;

- контроль;

- конкуренція.

Розмір кожного вектору для кожного окремо взятого банку $є$ різним і визначається вибраною стратегією розвитку, а саме орієнтирами, місією, цілями, планами (рис. 2).

Ключове значення реалізації організаційних цінностей полягає в тому, що хоча більшість банків прагне мати організаційну культуру, яка охоплює всі чотири квадранти, проте кожен банк, як правило, буде найсильнішим в одному квадранті, а ця сила матиме великий вплив на те, як банк діє, де він $€$ найбільш успішним, що він вважає найбільш складним.

Наприклад, банк зі створенням культури буде постійно виходити з новими фрінансовими продуктами й досягати високого рівня органічного зростання, але матиме найбільшу складність у підтримці стандартів контроля ризиків та усунення помилок відповідності нормативним вимогам.

Аналогічним чином банк з корпоративною культурою, орієнтованою на створення конкурентних переваг, буде конкурентноздатним на ринку, вигравши більшість своїх битв за ринкову частку, а також буде рости агресивно через придбання інших слабших банків.

Використання корпоративних цінностей дає змогу будь-якій організації оцінити свою нинішню культуру, а також спроєктувати орієнтири її покращення. Орієнтири вибираються 3 огляду на діагностичний інструмент, який був підтверджений великими дослідженнями організаційної поведінки. Проводяться опитування будь-якої групи працівників про організаційну практику та її співвідношення 3 індивідуальною поведінкою. Відповіді потім можуть бути агреговані та усереднені для того, щоби створити карту поточних і бажаних орієнтирів та фрорм корпоративної культури. Знаючи свою мету, організація може залучати працівників до обговорення того, як ця зміна культури може бути досягнута.

Висновки 3 проведеного дослідження. Незважаючи на те, що Україна давно увійшла у світовий фрінансовий простір та бере активну участь у глобальному русі капіталу, все ж таки існує потреба вдосконалення засобів та інструментів реалізації стратегії розвитку, зокрема фрормування фрілософрії підприємства, з якою споживач швидше знайомиться, ніж з його продуктами. Культура банку повинна підтримувати виконання стратегії, впливати на всі аспекти прийняття рішень. Іншими словами, корпоративна культура - це набагато більше, ніж твердження про етичну поведінку в банках, адже вона вбудована в загальні операції, що стосуються найму працівників, винагород та звільнень, розподілу ресурсів та управління ризиками.

\section{БІБЛІОГРАФІЧНИЙ СПИСОК:}

1. Сайт Міністерства фрінансів України. URL: https://minfin.com.ua/ua/company/ukrsibbank/review (дата звернення: 26.02.2020).

2. Сайт «Таскомбанк». URL: https://mind.ua/banks/ 13-taskombank (дата звернення: 27.02.2020).

3. Гриненко А., Іщанова М. Корпоративна культура соціально-відповідального банку. Україна: аспекти праці. 2015. № 2. С. 11-17.

4. Сайт «ПриватБанк». URL : https://privatbank.ua/ about (дата звернення: 26.02.2020).

5. Сайт «ПУМБ». URL: https://www.pumb.ua (дата звернення: 26.02.2020).

6. Сайт «Кредобанк». URL: https://www.kredobank. com.ua (дата звернення: 26.02.2020).

7. Сайт«Укргазбанк».URL:https://www.ukrgasbank. com (дата звернення: 26.02.2020).

8. Сайт банку «Південний». URL: https://bank.com. ua/ua (дата звернення: 26.02.2020).

9. Сайт «Райфрайзен Банк Аваль». URL: https://www.aval.ua/about/misiya (дата звернення: 26.02.2020).

10. Сайт «Ощадбанк». URL: https://www.oschadbank. ua/ua (дата звернення: 26.02.2020).

11. Сайт ПАT «Універсал Банк». URL: https://www.universalbank.com.ua (дата звернення: 26.02.2020).

12. Jański J. URL: https://www.karierawfinansach.pl/ artykul/wiadomosci/co-bedzie-ryzykiem-nr-1-w-2014roku (дата звернення: 26.02.2020).

13. Мельник П., Зелена М. Корпоративна культура як чинник успішності компанії. Причорноморські економічні студії. 2016. № 4. С. 67-70.

14. Сайт Організації міжнародного співробітництва і розвитку. URL: https://bank.gov.ua/doccatalog/ document;jsessionid=88CE336067904F8C70ECE96C $1 \mathrm{AE} 38 \mathrm{~B} 6 \mathrm{~A}$ ? $\mathrm{id}=50650698 \& \mathrm{fbclid}=\mathrm{IWAR} 2 \mathrm{pP} 60 \mathrm{a}$ EhJZEvInsU0rXmzEPf3Q3Xemw_S27kcr1 LOLUcIn2jvO5sPNTyQ (дата звернення: 6.02.2020).

\section{REFERENCES:}

1. Sait Ministerstva finansiv Ukrainy. URL: https://minfin.com.ua/ua/company/ukrsibbank/review (accessed 26 February 2020).

2. Sait "Taskombank". URL: https://mind.ua/ banks/13-taskombank (accessed 27 February 2020).

3. Hrynenko A., Ishchanova M. (2015) Korporatyvna kultura sotsialno-vidpovidalnoho banku [Corporate culture of socially responsible bank]. Ukraina: aspekty pratsi. № 2, pp. 11-17.

4. Sait "PryvatBank". URL: https://privatbank.ua/ about (accessed 26 February 2020).

5. Sait "PUMB". URL: https://www.pumb.ua (accessed 26 February 2020).

6. Sait "Kredobank". URL: https://www.kredobank. com.ua (accessed 26 February 2020).

7. Sait "Ukrhazbank". URL: https://www.ukrgasbank. com (accessed 26 February 2020).

8. Sait banku "Pivdennyi". URL: https://bank.com.ua/ ua (accessed 26 February 2020).

9. Sait "Raifaizen Bank Aval". URL: https://www.aval.ua/about/misiya (accessed 26 February 2020). 
10. Sait"Oshchadbank". URL:https://www.oschadbank. ua/ua (accessed 26 February 2020).

11. Sait PAT "Universal Bank". URL: https://www.universalbank.com.ua (accessed 26 February 2020).

12. Jański J. URL: https://www.karierawfinansach.pl/ artykul/wiadomosci/co-bedzie-ryzykiem-nr-1-w-2014roku (accessed 10 February 2020).

13. Melnyk P., Zelena M. (2016) Korporatyvna kultura yak chynnyk uspishnosti kompanii
[Corporate culture as a factor of success of the company]. Prychornomorski ekonomichni studii. № 4, pp. 67-70.

14. Sait Orhanizatsii mizhnarodnoho spivrobitnytstva i rozvytku. URL: https://bank.gov.ua/ doccatalog/document;jsessionid=88CE336067904 F8C70ECE96C1AE38B6A? id $=50650698 \&$ fbclid= IwAR2pP60aEhJZEvInsU0rXmzEPf3Q3Xemw S27kcr1LOLUcIn2jvO5sPNTyQ (accessed 6 February 2020). 